\title{
Correction to: Operationalizing a Conceptual Model of Colorism in Local Policing
}

\section{Henry Smart III ${ }^{1} \mathbb{D}$}

Published online: 17 December 2018

○) Springer Science+Business Media, LLC, part of Springer Nature 2018

\section{Correction to: Social Justice Research https://doi.org/10.1007/s11211-018-0318-5}

The article Operationalizing a Conceptual Model of Colorism in Local Policing, written by Henry Smart III, was originally published electronically on the publisher's Internet portal (currently SpringerLink) on 21 November 2018 with open access.

With the author(s)' decision to reverse the Open Choice, the copyright of the article changed on 27 November 2018 to (C) Springer Science+Business Media, LLC, part of Springer Nature and the article is forthwith distributed under the terms of copyright.

The original article has been corrected.

The original article can be found online at https://doi.org/10.1007/s11211-018-0318-5.

\section{Henry Smart III}

hsmart@jjay.cuny.edu

1 John Jay College, 524 W. 59th Street, New York, NY 10019, USA

记 Springer 